\title{
O uso de células-tronco na oftalmologia
}

$\mathbf{N}$ os últimos anos, o assunto "células-tronco" tem sido muito debatido, e é objeto frequentemente exposto na mídia. Com o aumento da expectativa de vida das populações de uma forma geral, estima-se que também aumente o número de indivíduos afetados por doenças crônico-degenerativas. Estas doenças representam um enorme custo social, além de um considerável gasto nos sistemas de saúde. As terapias celulares têm sido consideradas como uma possível alternativa para oferecer cura e/ou interrupção da progressão de algumas dessas doenças para as quais a medicina atual não oferece recursos terapêuticos.

Estima-se que o mercado para produtos e serviços que envolvam terapias celulares seria de cerca de US\$ 24,6 bilhões em 2005 e que possa chegar a US\$ 68,9 billhões em 2010. Nos EUA, onde a legislação permite patentear linhagens celulares e tecnologias que envolvam o uso de células-tronco, já foram concedidas mais de 2.000 patentes relevantes para uso em doenças e há mais de 100 companhias que detêm patentes relacionadas ao uso de terapias celulares em humanos. Se algumas destas linhagens patenteadas se tornar uma terapia, nos veremos na situação de ter que pagar para utilizar estas células, apesar da legislação do Brasil ser contrária.

No início de março deste ano, o presidente dos Estados Unidos, Barack Obama, assinou um decreto suspendendo as restrições ao uso de fundos federais em pesquisas com células-tronco embrionárias. Em um ato na Casa Branca, o chefe de Estado disse que a ciência não está "brigada" com os valores morais. "Apoiaremos totalmente os cientistas envolvidos nestas pesquisas", acrescentou Obama, ao emitir uma ordem executiva que reverte uma política imposta em 2001, por seu antecessor, George W. Bush, e um memorando para restabelecer a "integridade científica".

Outra notícia recente que também "esquentou" a mídia foi a de Dakota Clarke,uma menina de 2 anos de idade, da cidade de Newtownabbey, na Irlanda do Norte, que nasceu com displasia septo óptica.Ela foi submetida a um tratamento no hospital de Qingdao, na China, com utilização de células-tronco retiradas do cordão umbilical e injetadas por via intravenosa. Após o tratamento, Dakota Clarke conseguiu ver contornos e cores dos objetos e distinguir luzes à sua volta .Apesar disso, ainda existe muitos questionamentos sobre este resultado que necessita de publicação e melhor avaliação quanto à resposta visual como, por exemplo através de um estudo eletrofisiológico.

Como a maioria das grandes novidades, esta área está sendo superestimada se for considerada a realidade atual, entretanto não há dúvidas de que as suas potencialidades são enormes, e pode-se esperar um novo tipo de Medicina a partir da evolução dessas pesquisas.

Recentes avanços no campo da pesquisa das células-tronco têm voltado sua atenção na aplicação da terapia celular para regenerar tecidos oculares que têm sido danificados por uma doença degenerativa ou injúria.

As células-tronco atualmente mais utilizadas em estudos clínicos são as células-tronco adultas que apesar de não substituírem as células de um órgão lesado, elas recuperam parcialmente a função destes órgãos por mecanismos ainda não totalmente compreendidos, mas que provavelmente envolvem a secreção de vários fatores (citocinas, fatores de crescimento, fatores antiapoptóticos, etc) pelas células injetadas. Este efeito parácrino tem sido cada vez mais valorizado, até mesmo porque as células injetadas parecem ter uma sobrevida no órgão lesado que nunca ultrapassa algumas poucas semanas.

Alguns estudos inclusive clínicos têm demonstrado a viabilidade de utilizar as células-tronco para reparar ou regenerar o epitélio da córnea. É compreensível que a superfície da córnea consiste em uma área anatômica fácil para utilização da terapia celular, pois estas células poderiam ser implantadas sem usar métodos invasivos. Assim até o presente momento, somente as células-tronco do epitélio límbico (limbal epithelial stem cells-LESC) usadas para o reparo da córnea apresentam aplicação clínica reconhecida no campo da oftalmologia. Experiências adquiridas com esta abordagem poderão potencialmente ajudar com o desenho de terapias baseadas em células-tronco para regenerar outros tecidos oculares, particularmente o epitélio pigmentado da retina (EPR) e a retina neural. Entretanto estes tecidos oculares consistem em estruturas complexas responsáveis pela função visual e a terapia celular ainda apresenta diversos problemas a serem resolvidos para a sua aplicabilidade.

Um aspecto fundamental que devemos lembrar é que diferentes partes do olho derivam de diferentes tipos de tecido embrionário: a retina neurossensorial e o EPR têm origem neuroectoderma, a esclera, córnea e úvea,originam do mesoderma e o cristalino do ectoderma. Portanto a regeneração de diferentes tecidos oculares 
possui um grande desafio devido a sua diversidade e também na complexidade de sua via neural representada pelas células da retina e nervo óptico. Neste contexto, a viabilidade da regeneração pode depender da complexidade dos tecidos a serem reparados. Por exemplo, a regeneração do EPR pode consistir em um alvo relativamente fácil para as células-tronco por ser uma simples monocamada de células. A retina neural, entretanto, pode requerer protocolos mais complexos para sua regeneração, pois apresenta multicamadas formadas de neurônios e células gliais.

Existe muita especulação na capacidade de novas fontes descobertas de progenitores da retina, mas antes de estabelecermos qualquer nova terapia, nós deveríamos entender a real potencialidade de cada fonte de célula para regenerar os neurônios da retina. Problemas para serem solucionados incluem padronização dos métodos de isolamento e expansão para preservar os fenótipos das células-tronco, a identificação dos requisitos para diferenciação neural e preparação de andaimes para o enxerto, modulação de matriz extracelular para promover a migração celular e sinapse neural, prevenção de rejeição imune e desenvolvimento de tumor e mais importante, a identificação de condições que mantenham a sobrevida do enxerto.

Apesar de muitos problemas práticos, existe um otimismo geral entre a comunidade médica e científica de que a terapia baseada nas células-tronco, para restaurar a função visual, pode tornar-se realidade em um futuro não muito distante.

\author{
Clínica e Centro de Pesquisa Rubens Siqueira em São José do Rio Preto(SP), Brasil \\ Disciplina de Oftalmologia da Faculdade de Medicina de Catanduva (SP), Brasil; Pesquisador do Departamento \\ de Retina da Universidade de São Paulo - Ribeirão Preto (SP), Brasil
}

